\title{
Effects of Cavitation on the Development of Pine Wilt Disease Caused by Bursaphelenchus xylophilus
}

\author{
Keiko Kuroda*, Toshihiro YamadA*, Kazuhiko Mineo** \\ and Hirotada TAMURA***
}

\begin{abstract}
Abnormal ascent of xylem-sap was investigated after the inoculation of Pinus thunbergii with Bursaphelenchus xylophilus, using acid-fuchsin solution injected into the bottom of trunks of standing trees at one week intervals prior to harvest. Results were considered in relation to decrease in xylem water content, anatomical changes, and increase of nematode number in the trees. When sap-flow was disturbed two weeks after nematode inoculation, the water content began to decrease, after which whitish streaks became conspicuous in the cross section of trunks very clearly bounded by the area stained with the dye. Tracheids in those areas showed "cavitation", that is, the phenomenon that tracheids come to contain gas instead of water. Xylem-sap flow, which ascended in spiral direction in healthy trees, was disturbed by the blockage of flow at cavitated tracheids. Areas of cavitation gradually spread to cover the entire cross sectional surface. Anatomical changes in pine tissue and increase in nematode number were delayed until the fourth week when water contents of xylem decreased to about $30 \%$ of healthy trees. Necrosis of cambium and phloem seemed to be caused by water shortage at the adjacent part to cavitated tracheids. Water deficit induced by cavitation was judged to be a major factor of inducing lethality in pine trees. Because resin leakage from epithelium was restricted to very small areas, mechanical plugging of water flow by leaked resin did not appear to be a major factor in disease induction. Clear boundaries between the cavitation and dye-stained areas suggested that hydrophobic substances were incorporated in cavitation areas. Investigations on the causal factors of cavitation may be required to understand the mechanism of pathogenesis associated with nematode infection.
\end{abstract}

(Received August 16, 1988)

Key words: pine wilt disease, cavitation, water deficit, nematode, Bursaphelenchus xylophilus, Pinus thunbergii.

\section{INTRODUCTION}

The pine wood nematode, Bursaphelenchus xylophilus, creates a disturbed water condition in the trunk of Pinus thunbergii and finally kills the pine tree ${ }^{6-8,12)}$. The mechanism of pathogenesis in pine wilt disease has not yet been elucidated.

Tamura et al..$^{21)}$ showed that xylem-sap flow ascended spirally in healthy trees ${ }^{10,11)}$ and that this ascent became random one or two weeks after infection with pine wood nematode. They assumed that the flow disturbance was due to partial blockage of tracheids by unknown factors, and that water bypassed to adjacent tracheids until the complete blockage occurred five weeks after infection. An abrupt increase in nematode numbers occurred subsequent to the conspicuous disturbance of sap flow.

\footnotetext{
*,***** Forestry and Forest Products Research Institute 農林水産省森林総合研究所

* Kansai Research Center, Momoyama, Fushimi, Kyoto 612, Japan 関西支所

** Shikoku Research Center, Asakuracho, Kohchi 780, Japan 四国支所

*** PO Box 16, Norin Kenkyu Danchi-nai, Ibaraki 305, Japan
} 
Tamura et al. ${ }^{21)}$ emphasized such tracheid blockage is an initial, and very significant, symptom before rapid multiplication of nematode population. Kozlowski') stated that vascular plugging often played a major role in the appearance of initial symptoms of wilt and in the ultimate death of infected plants. The cause of vascular plugging, however, is controversial in many tree diseases $^{1-3,5)}$. In the case of pine wilt disease, the mechanism of water blockage in relation to the death of pine trees has been poorly investigated. For instance, abnormal water relations have been suggested from water stress and abnormal respiration ${ }^{13,19,20)}$ but no one yet has directly measured xylem water status. This is probably because no one regarded drying of xylem as the cause of death but the results. Toxic substances ${ }^{16,22)}$ have been reported, but not been shown to be the cause of tracheid blockage. Hydrolytic enzymes were thought to cause resin leakage ${ }^{15}$. However, mechanical plugging of tracheids with resin or degraded substances ${ }^{17}$, which were speculated to cause water blockage, has not been experimentally proven.

In this report we first explain the timing from initial wilt symptom onset until the death of pine trees in relation to the water conduction, water distribution, growth of nematode population, and anatomical changes of pine cells. Next we discuss mechanism of water blockage and resulting effects of water deficit on the survival of pine trees, based on the investigation of xylem-sap flow and xylem water contents. Before discussing how pine trees are killed by pine wood nematode, the causal factor of water flow blockage must be discovered.

\section{MATERIALS AND METHODS}

Inoculation and sampling. Twelve 11-year-old Japanese black pines (Pinus thunbergii) were selected in the nursery of Kansai Research Center, Forestry and Forest Products Research Institute. A branch of each tree was inoculated with 10,000 pine wood nematodes, Bursaphelenchus xylophilus, at a height of $c a .200 \mathrm{~cm}$ (Fig. 1) on August 18, 1987. Each week for one month, 3 sample trees were injected with $1 \%$ aqueous acid-fuchsin via a hole drilled at a height of $30 \mathrm{~cm}$ above ground. Trees were cut the next day. Methods used for dye injection, nematode culture, inoculum preparation, and tree inoculation were the same as in the previous report ${ }^{21)}$. Control

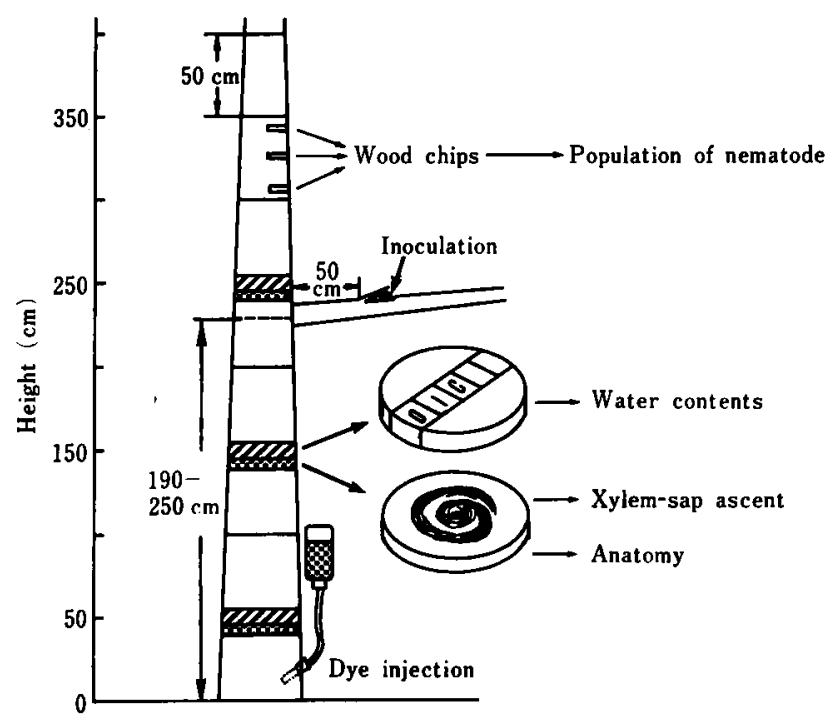

Fig. 1. Schematic illustration of the nematode inoculation and sampling site from a pine tree. Vertical axis indicates the height of inoculated branch and disk sampling. 
trees not inoculated with pine woud nematode were harvested three times after the injection with dye solution during the experiment.

The site of sampling from each tree is illustrated in Fig. 1 . Two disks, 2 and $3 \mathrm{~cm}$ thick, were cut from the trees at 3 points, 50,150 , and $250 \mathrm{~cm}$ above ground. The $3 \mathrm{~cm}$ thick disk from each height was used for water-content measurement. The other disk cut adjacent to $3 \mathrm{~cm}$ disk was used for anatomical observation. Disks also were cut from control trees for the same purpose.

Water contents. Water content of xylem was measured at 5 points across the diameter of the $3 \mathrm{~cm}$ disks taken from three heights of each tree (Fig. 1). Water content was calculated from fresh weight (FW) and dried weight (DW) (oven-dried at $105 \mathrm{C}$ for one night), and was expressed as percent water in dried wood $[\{(\mathrm{FW}-\mathrm{DW}) / \mathrm{DW}\} \times 100 \%]$. The relative water content $(\mathrm{RWC})$ was estimated based on average water contents at three heights of inoculated trees (WCI) and those of three control trees $(\mathrm{WCC})[(\mathrm{WCI} / \mathrm{WCC}) \times 100 \%]$.

Distribution of nematode. To learn the distribution and growth of the nematode population, samples were harvested every $50 \mathrm{~cm}$ from the base of tree to a height of $400 \mathrm{~cm}$ with a drill as illustrated in Fig. 1. Pine wood nematode was extracted from xylem chips by the Baermann funnel method and counted. In addition, part of the samples were sealed in polyethylene films and kept for one month at room temperature to accelerate the multiplication of nematodes in wood, in order to detect the nematodes that were in very small numbers at harvest (incubation method).

Macro- and microscopy. Disturbance of dye ascent was first checked on the disks prepared for anatomy. The disks were cut into small blocks $(1 \times 2 \times 2 \mathrm{~cm})$ and fixed in FAA (formalin, acetic acid, 30\% ethanol; $5: 5: 90 \mathrm{v} / \mathrm{v}$ ). Two or three days later, they were washed with tap water for one day. Blocks were observed with a stereo microscope and some of them were embedded in gelatin in order to retain small contents of tracheids. The blocks were soaked in $10 \%$ gelatin solution for 2 days, and then transferred to $20 \%$ gelatin solution for 3 days at $37 \mathrm{C}$. After cooling, the blocks were hardened in $10 \%$ formalin. Cross, radial and tangential sections of $20-30 \mu \mathrm{m}$ thick were cut with a sliding microtome, and were stained with sudan III or nile blue.

After sampling disks and xylem chips, bark of inoculated branches and a part of trunks were removed to allow examination of the condition of inner bark and cambial region of pine tissue. Leaf color also was checked.

\section{RESULTS}

\section{Pattern of dye ascent and water contents}

Disturbed pattern of dye ascent in the inoculated pine woods was first seen 2 weeks after the infection (Plate I. Compare 1 and 2). Dye ascent did not show a clear spiral pattern, although the trunk absorbed the dye-solution well. Change in water distribution was detected at the same time as a local decrease in water content (Fig. 2) indicating that water conduction by tracheids decreased in infected trees. The relative water contents varied among individual trees and also among their height from 44 to $88 \%$ of that seen in healthy trees (Table 1). Later in the infection, dye ascent never showed a spiral pattern (Plate I-3, 4). Water content decreased in asymmetrical pattern across the diameter of disks from 2 weeks after infection.

Unstained and very conspicuous white streaks, which were clearly bounded by areas stained with aqueous dye solution, were found on the disk surface of trees 3 weeks after infection (Plate I-3, arrow). Streaks were detectable from 2 weeks after the inoculation by observation with a stereo microscope (Plate I-2, 6A). They were long radially and extended in longitudinal direction (Plate I-7A). Tracheids in these areas appeared to lack water. The whitish areas were clearly detected even in the upper parts of trunks at height $250 \mathrm{~cm}$ where dye solution did not reach and the xylem was not stained. 


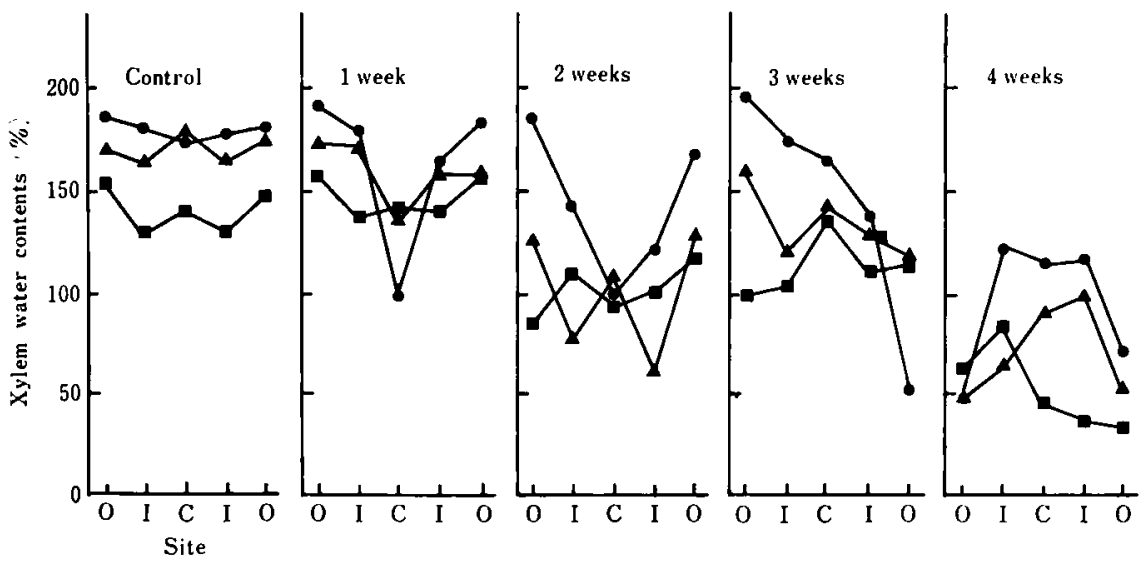

Fig. 2. Decrease in xylem water-contents of Pinus thunbergii inoculated with Bursaphelenchus xylophilus. Representative one of three sample trees at each sampling date. height $50 \mathrm{~cm}, \Delta 150 \mathrm{~cm},-250 \mathrm{~cm}$. O: outer rings, I: inner rings, C: center of disks (See Fig. 1).

Table 1. Water contents at three heights of stand trees of Pinus thunbergii inoculated with Bursaphelenchus xylophilus

\begin{tabular}{|c|c|c|c|c|c|c|c|}
\hline \multirow{3}{*}{$\begin{array}{l}\text { Weeks after } \\
\text { inoculation }\end{array}$} & \multirow{3}{*}{$\begin{array}{c}\text { Sample } \\
\text { No. }\end{array}$} & \multicolumn{6}{|c|}{ Height $(\mathrm{cm})$} \\
\hline & & \multicolumn{3}{|c|}{ Water contents a) } & \multicolumn{3}{|c|}{ Relative water contents b) } \\
\hline & & 50 & 150 & 250 & 50 & 150 & 250 \\
\hline \multirow[t]{3}{*}{1} & 1 & 189 & 209 & $218 \%$ & 120 & 120 & $118 \%$ \\
\hline & 2 & 148 & 160 & 164 & 94 & 92 & 89 \\
\hline & 3 & 144 & 156 & 163 & 92 & 90 & 89 \\
\hline \multirow[t]{3}{*}{2} & 1 & 101 & 101 & 143 & 64 & 58 & 78 \\
\hline & 2 & 111 & 76 & 162 & 71 & 44 & 88 \\
\hline & 3 & 84 & 89 & 109 & 54 & 51 & 59 \\
\hline \multirow[t]{3}{*}{3} & 1 & 110 & 134 & 145 & 70 & 77 & 79 \\
\hline & 2 & 109 & 143 & 135 & 69 & 82 & 73 \\
\hline & 3 & 78 & 112 & 140 & 50 & 64 & 76 \\
\hline \multirow[t]{3}{*}{4} & 1 & 70 & 112 & 130 & 45 & 64 & 71 \\
\hline & 2 & 52 & 70 & 94 & 33 & 40 & 51 \\
\hline & 3 & 50 & 92 & 115 & 32 & 53 & 63 \\
\hline \multirow[t]{3}{*}{ Control } & 1 & 143 & 151 & 159 & & & \\
\hline & 2 & 140 & 171 & 182 & & & \\
\hline & 3 & 188 & 201 & 210 & & & \\
\hline \multicolumn{2}{|c|}{ Average of controls } & 157 & 174 & $184 \mathrm{c})$ & 100 & 100 & 100 \\
\hline
\end{tabular}

a) Averaged water contents of five points on a disk at each height.

b) Calculation based on the averaged water contents of three control trees (c).

c) Averaged water contents of control trees without inoculation.

The white areas fanned out (Plate I-8), and reached the cambium almost entirely covering the trunk cross section at 4 weeks after infection (Plate I-4). At this time, the relative water contents in xylem decreased to $c a .30 \%$ especially near the tree's base by that time (Table 1 ).

Nematode distribution

As judged from the result of one month incubation (Fig. 3), pine wood nematode was already 

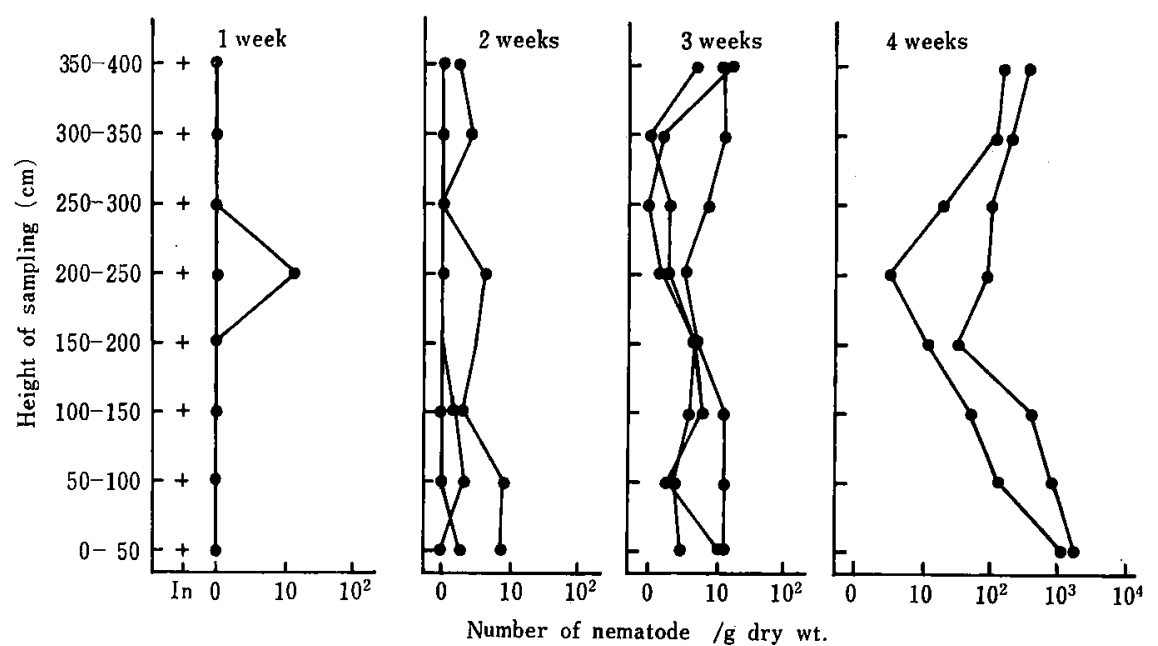

Fig. 3. Distribution of pine wood nematode in the trunks of nematode inoculated pines, immediately after the harvest (๑) and after the incubation of a month (In). Existence of nematode checked by incubation method is indicated by $(+)$.

distributed throughout the trunks one week after infection. The number of nematodes, however, apparently was very small, because they were not detected by the direct soaking of xylem chips into water. Number of nematodes increased rapidly to $10^{3} / \mathrm{g}$ (dried wood) 4 weeks after the inoculation.

\section{Changes in pine tissue}

In contrast to the rapid distribution of nematodes throughout the trunks and decrease of water contents within two weeks of infection, denaturation of pine tissue was delayed. Discoloration of phloem, indicating necrosis of phloem parenchyma cells, was restricted to the inoculated branches even 3 weeks after inoculation (Plate I-5). In all cases the discoloration did not extend across the base of inoculated branches. Necrosis of cambium was detected in the main stem 4 weeks after inoculation (Plate I-4) when the water contents of outer rings decreased to $50 \%$, less than one-third of the water content of control disks (150 to $180 \%$ ) (Fig. 2, Table 1). The necrosis was observed where the cambium contacted the cavitation area. In most samples, resin leaking from epithelium to surrounding tracheids was not conspicious even 3 weeks after the inoculation, and was rarely observed in very tiny areas (Plate I-8).

Microscopic observations of sections cut from three plants indicated that areas of white streaks were filled with gas. This indicates the cavitation of tracheids. As shown in Plate I-6, in some cross sections cut from the second week's sample, only a few tracheids inside or adjacent to the broad cavitation areas were plugged with an unidentified material which was stained with nile blue. Such plugging was not detected in all samples even 3 weeks after inoculation (Plate I-8). Plugged areas were usually found in the late wood. These coincide with the site of resinosis in some cases. The plugged tracheids, however, did not always have contact with resin canals. In tangential sections of gelatin-embedded samples, droplets stained with nile blue were found scattering in some of the cavitated tracheids (Plate I-7B, C), although the amount was very small. Bordered pits on the tracheid walls seldom covered with the droplets. Some droplets exuded from ray parenchyma cells through the pits (Plate I-7B). Plugging material, or droplets were seldom observed along horizontal resin canals.

These symptoms of pine wilt disease are summarized in Table 2 together with other well known symptoms. 
Table 2. Symptoms of pine wilt disease during the lapse of time after pine-wood-nematode infection

\begin{tabular}{cl}
\hline $\begin{array}{l}\text { Weeks after } \\
\text { inoculation }\end{array}$ & Symptoms \\
\hline 1 & $\begin{array}{l}\text { Distribution of nematodes throughout trunks (Incubation method) } \\
\text { Disturbance of spiral sap ascent } \\
\text { Local decrease of xylem water contents } \\
\text { Start of cavitation as white streaks } \\
\text { Partial necrosis of phloem in inoculated branches } \\
\text { Discoloration of old leaves } \\
\text { Phloem necrosis in inoculated branches } \\
\text { Development of cavitation and decrease of xylem water contents } \\
\text { Extensive increase in nematode number } \\
\text { Decrease in water contents to one-third of that in healthy tree } \\
\text { Enlargement of cavitation to cambium } \\
\text { Necrosis of cambium and phloem in trunks }\end{array}$ \\
\hline
\end{tabular}

\section{DISCUSSION}

Local blocking of xylem-sap ascent started within two weeks after infection of pines with pine wood nematode. This is judged to be the point at which physiological characters of the infected tree changes especially in terms of water relations (Table 2). Before this time, there is no resinosis, no necrosis of parenchyma and cambial cells, and no abrupt increase in nematode number. Prior to onset of well known symptoms of pine wilt disease, a noticeable phenomenon called cavitation of tracheids ${ }^{6)}$ was present as radial streaks in the xylem. Tracheids within these areas contained gas or vapor and the sap ascent is blocked at the cavitation areas. In healthy trees, xylem sap ascends spirally through the tracheid pits on radial wall ${ }^{10,11)}$. It is difficult to move water in a radial direction, since early-wood tracheids do not have pits on tangential walls ${ }^{4)}$. When a group of tracheids aligning radially did not conduct water because of cavitation, water flow in the xylem must change direction to make a zigzag pattern until complete blockage occurred by enlarged cavitation. Decrease in water contents from 2 weeks after infection reflects enlarging areas of cavitation.

Sasaki et al. ${ }^{17)}$ reported white patches in juvenile pine trees which resemble the white streaks found in this experiment. Such symptom of cavitation, in other word xylem drying, was also described in many reports on fungal disease caused by Ceratocystis, Peridermium, Fomes and others in conifers ${ }^{1-3,5)}$. Inducing factor of such area called dry zone or pathological heartwood is controversial. Pine wilt disease is different from those fungal disease in the characteristic that the cavitation development is much more drastic.

Cambial necrosis was first observed 4 weeks after inoculation, when the water contents decreased to $50 \%$ in outer rings (Fig. 2). It was reported that sapwood in Pinus species became nonconducting when its moisture contents reached $65-85 \%^{2}$. Pinus densiflora was reported to die when its water contents reduced to half of that found in healthy trees ${ }^{18}$. These reports suggest xylem-sap in nematode infected pines is not enough for the trees to survive when cambial necrosis started. In addition, necrotic areas in cambium coincides with the parts where enlarged cavitation area began to contact the cambium. Cambium must be difficult to retain activity in areas where water deficit occurred. This condition well explains that extensive cavitation induces water deficit and results in cambial necrosis. If toxic chemicals or harmful enzymes are produced by the nematode, they are supposed to function to cause a water deficit.

Assuming water deficit leads to pine tree death, the reason for water blockage becomes very significant. Mechanical plugging with solid or liquid, and vapor plugging, for instance, are considered. Whether resin functions to block sap flow in wide area of trunk is doubtful ${ }^{12)}$. In 
the present experiment, two types of xylem contents in the liquid state were found. One plugged tracheids and the other scattered as droplets exuding from ray cells. Unidentified materials both were stained with nile blue, dye for lipid. Nobuchi et al. ${ }^{14)}$ supposed the substances stained with nile blue were derived from parenchyma cells, probably the epithelium of axial resin canals. It has not been proven whether the plugging material is identical with resin or not. On the other hand, droplets in the tracheids are ascertained to be produced by ray cells, and the constituents must be different from resin. This phenomenon indicates there are metabolic changes in ray parenchyma cells in the cavitation areas. Judged from the limited distribution of plugging material and droplets, it is unlikely that cavitation results from mechanical plugging with these unidentified materials. Cavitation areas may contain other substances in vapor state. At least, constituent of the gas must be different from "air" ${ }^{23)}$.

Results of the present experiment suggested the resin leakage into tracheids was not a main factor of tracheid blockage, but occurred accompanying or following cavitation. Leaked resin has been supposed as the cause of white patches by Sasaki et al. ${ }^{17)}$ based on the results of experiment using one-year-old pine trees. But we did not find such drastic resinosis in our experiment with 11-year-old trees. Timing and manner of resinosis, cell necrosis, and duration to the death indicate significant difference due to the age of trees used ${ }^{12)}$. In the case of juvenile trees, reaction of pine tissue to the nematode infection is very fast.

Vapor blockage of tracheid is thought to be effective as a cause of cavitation ${ }^{2,23)}$. However, it is questionable whether the vapor is air coming from outside of the bark through ray tissue because cavitation develops inside xylem and does not penetrate cambium to pholem. The clear boundary of cavitation as outlined by the dye suggests that tracheids in such areas contain some hydrophobic substances which prevent the dispersal of water-soluble dye. Such chemicals may be synthesized in parenchyma cells and dispersed through pits, and may function to cause cavitation if they are volatile substances. Analysis of gas filled in cavitated tracheids will reveal this. After the initiation of cavitation, cut off of the water column will be accelerated under negative pressure of water stress in summer time ${ }^{23)}$.

The nematodes dispersed throughout trunks before the local inhibition of xylem-sap flow although the number was very small. Dispersal of nematodes already has been pointed out to be very fast ${ }^{19}$. Abrupt increase in nematode number at the last stage of this disease was not thought to be the cause of wilt ${ }^{21)}$. Nevertheless, the movement and feeding activity of widely dispersed nematodes in the early stage has not been paid attention, because nematodes are seldom detected by one week after the inoculation by ordinary sampling method ${ }^{21)}$. Active and fast movement of this pathogenic nematode may have significant effects different from most diseases of conifers induced by fungi. In these diseases the lesion and dry zone enlarge slowly in trunks ${ }^{2,5)}$. When discussing symptoms of this wilting disease and the ultimate death of the tree, effects of wounding by nematodes actively migrating throughout the tree during the early period after infection should not be neglected.

The present experiment demonstrated the following two facts: first, cavitation induced by inoculation with the pine wood nematode causes water deficit throughout the trunk and finally leads to death of pine trees; second, cavitation occurs early and in wide spread areas compared with tracheid plugging with resin or unidentified material. In order to detect the causal substances of tracheid cavitation, analysis of gas included in the areas of tracheid cavitation is now under investigation.

We wish to thank Prof. R.F. Myers, Rutgers University, U.S.A. and Prof. R. Bolla, University of Missouri-St. Louis, U.S.A. for their critical reading of the manuscript.

\section{Literature cited}

1. Basham, H.G. (1970). Phytopathology 60: 750-754.

2. Coutts, M.P. (1976). Eur. J. For. Pathol. 6: 372-381. 
3. Coutts, M.P. (1977). Ibid. 7: 6-12.

4. Esau, K. (1965). Plant Anatomy 2nd ed. John Wiley \& Sons, New York.

5. Gregory, S.C. (1977). Eur. J. For. Pathol. 7: 328-338.

6. Ikeda, T. and Suzaki, T. (1984). J. Jpn. For. Soc. 66: 412-420.

7. Kiyohara, T. and Suzuki, K. (1978). Eur. J. For. Pathol. 8: 285-292.

8. Kiyohara, T. and Tokushige, Y. (1971). J. Jpn. For. Soc. 53: 210-218.

9. Kozlowski, T.T. (1968). Water Deficits and Plant Growth. Vol. 1. Academic Press, New York. pp. 1-21.

10. Kozlowski, T.T., Hughes, J.F. and Leyton, L. (1967). Forestry 40: 207-219.

11. Kozlowski, T.T. and Winget, C.H. (1963). Bot. Gaz. 124: 301-311.

12. Kuroda, K., Suzuki, K. and Yamada, T. (1984). Trans. Ann. Mtg. Jpn. For. Soc. 95: 471-472.

13. Mamiya, Y. and Tamura, H. (1977). J. Jpn. For. Soc. 59: 56-63.

14. Nobuchi, T., Tominaga, T., Futai, K. and Harada, H. (1984). Bull. Kyoto Univ. For. 56: $224-233$.

15. Odani, K., Sasaki, S., Nishiyama, Y. and Yamamoto, N. (1985). J. Jpn. For. Soc. 67: 366-372.

16. Oku, H., Shiraishi, T. and Kurozumi, S. (1979). Naturwissenshaften 66: 210-211.

17. Sasaki, S., Odani, K., Nishiyama, Y. and Hayashi, Y. (1984). J. Jpn. For. Soc. 66: 141-148.

18. Satoo, T. (1956). Bull. Tokyo Univ. For. 51 : 1-108.

19. Suzuki, K. (1984). Bull. For. \& For. Prod. Res. Inst. (Japan) 325: 97-126.

20. Suzuki, K. and Kiyohara, T. (1978). Eur. J. For. Pathol. 8: 97-107.

21. Tamura, H., Mineo, K. and Yamada, T. (1987). Jpn. J. Nematol. 17: 23-30.

22. Ueda, T., Oku, H., Tomita, K., Sato, K. and Shiraishi, T. (1984). Ann. Phytopath. Soc. Japan 50: 166-175.

23. Zimmermann, M.H. (1983). Xylem Structure and the Ascent of Sap. Springer-Verlag, Berlin.

\section{和 文 摘 要}

黒田慶子・山田利博・峰尾一彦・田村弘忠：マッ材線虫病の病徵進展におけるキャビテーションの影響

11 年生クロマッにマッノザイセンチュウを接種し，1 週間ごとの伐倒の前日に根元から染色剂を吸収 させて，その上昇バターンから木部の通水異常を検出した。木部含水率を測定し，通水異常との関係を明ら かにすると同時に, マッ組織の変化、線虫の増殖との関保を調べた。接種 2 週後に水分の上昇に乱れが観 察され，含水率が低下し始めた。樹幹の木口断面では，放射方向に長く白色の線状ないし紡鏵形の部分が， 染色部と明確に区分されて出現した。この部分では仮道管は水を失い，気体がっていた。この現象は「キ ナビテーション（空洞化）と呼ばれる。健全な樹木では，木部の水はらせん状に上昇するが，線虫接種木 ではキ+ビテーション部位で流れが妨げられて通水ハターンが乱れる。キービテーションの範囲はしたいに 拡大し, 4 週後には木口断面のほぼ全面を覆った。マッ組織の変化と線虫の增殖は 4 週後, 木部の含水率 が健全木の 30\% に低下してからであった。これらの事実から, 形成層や師部の壊死はキャビテーション部 位に接した後に水不足により起こったものと判断した。仮道管のキャビテーションがーツの枯死の直接的原 因である可能性が高い。他方，漏出した樹脂による仮道管通水の機械的阻害は，非常に小さな範囲に留まる ため, 枯死の主因とは考えにくい。染色の阻止状況から，柾水性の物質がキャビテーション部位の仮道管内 に存在することが示唆された。マッノザイセンチュウがなぜマッを枯らすのかを明らかにするためには，ま ナ゙キャビテーションの原因を解明する必要がある。

\section{Explanation of plates}

Plate I. Disordered sap-ascent and tracheid cavitation in xylem of Pinus thunbergii inoculated with Bursaphelenchus xylophilus.

1. Disk surface of a control tree without nematode inoculation. Dye (acid fuchsin) injected from a hole at the base of trunk ascends in spiral pattern.

2. Disturbed ascent of dye 2 weeks after the nematode inoculation (height: $50 \mathrm{~cm}$ ).

3. Three weeks after the inoculation. White streaks are clearly visible (arrow) surrounded by stained areas at the hight of $50 \mathrm{~cm}$.

4. Four weeks after the inoculation. Cavitation areas enlarged to the cambium. Cambial necrosis progressed in the area where the cavitation area contacts the cambium (arrowheads).

5. Phloem and cambial necrosis stopped at the base of inoculated branch (arrow) even 3 weeks after the inoculation. 


\section{Plate I}
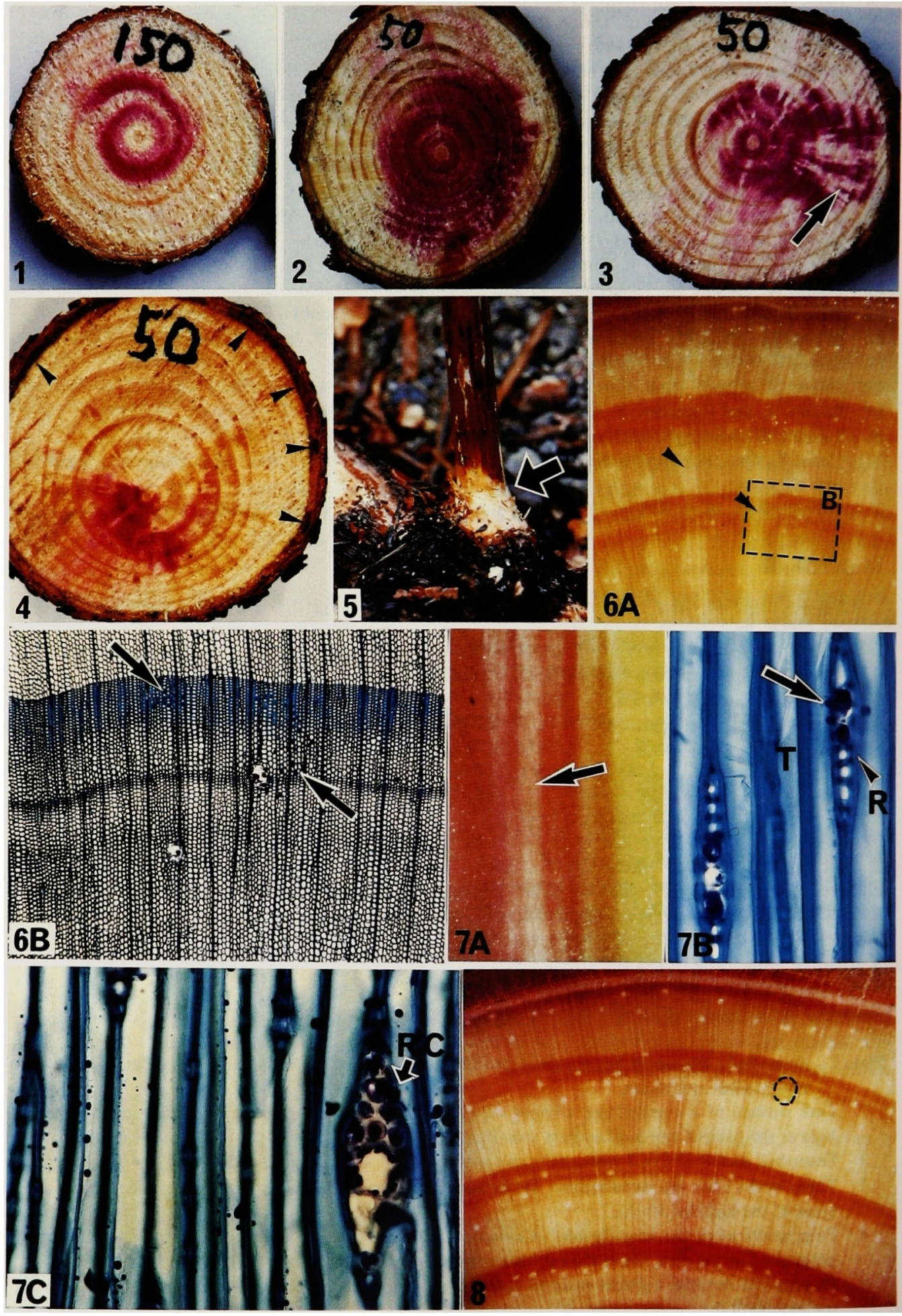
6. Tracheid cavitation and plugging 2 weeks after the inoculation.

A. Vapor-filled tracheids shown as white streaks (arrowheads) on the block observed with stereo microscope. $(\times 4.3)$

B. A cross section cut from the same block (column B in photo 6A). Plugging material (arrows) is observed stained with nile blue in only a small number of tracheids adjacent to cavitation area. Most part of cavitation areas are without any plugging. $(\times 38)$

7. Tangential plane of cavitation area 2 weeks after the inoculation.

A. Stereoscopic observation shows longitudinally extending cavitation (arrow). ( $\times 4.3)$

B. A tangential section indicates droplets stained with nile blue are exuding from ray parenchyma cells into tracheid (arrow). R: ray parenchyma tissue, T: tracheid. $(\times 190)$

C. Distribution of droplets in the cavitation area. RC: horizontal resin canal. $(\times 190)$

8. Enlarged cavitation 3 weeks after the inoculation. Cavitation area is whitish part occupying twothird of the photo. Resin leaks in a very small area (encircled). ( $\times 4.3)$ 